\title{
Comparative growth analysis, yield and quality of two cowpea (Vigna unguiculata L. (Walp.)) lines propagated by seed and stem cuttings
}

\author{
Bolaji Umar OLAYINKA ${ }^{1}$, Mubarak Akinbode AKINWUNMI ${ }^{1}$, Hameed ALSAMADANY², Abdulbaki \\ Shehu ABDULBAKI ${ }^{2,3,4}$, Yahya ALZAHRANI ${ }^{2}$, Emmanuel Obukohwo ETEJERE ${ }^{1}$
}

Received January 19, 2019; accepted September 29, 2019.

Delo je prispelo 19. januarja 2019, sprejeto 29. septembra 2019.

Comparative growth analysis, yield and quality of two cowpea (Vigna unguiculata L. (Walp.)) lines propagated by seed and stem cuttings

Abstract: In the present study, a field experiment was carried out to evaluate and compare the effects of seed planting and stem cutting method of propagation on two cowpea lines (IT07K-243-1-2 and IT07K-298-15). Data assessed were subjected to student t-test to test for the significant effect of the two methods at $p \leq 0.05$. Results showed that growth characters such as plant height, number of leaves, leaf area, above-ground dry mass, leaf area index, leaf area ratio, relative growth rate, net assimilation rate and crop growth rate were significantly enhanced in seed propagation method compared to stem cutting. The yield components such as number of matured pods per plant, pod mass per plant, pod length, pod circumference, pod filling, hundred (100) seed mass, seed mass per plant, average number of seed per pod, harvest index and pod yield per metre square followed similar pattern as recorded for growth characters. Germination potential of the harvested seeds as well as vigour were better in seed planting than stem cutting. Varietal difference showed that line IT07K-298-15 had higher growth, yield and germination potential than IT07K-243-1-2. However, the protein, fat and carbohydrate contents of the latter were higher than the formal. The study concluded that the use of true seed promoted higher productivity. However, planting of stems could still be encouraged on account of a non-significant difference in some of the aforementioned attributes, thereby limiting overreliance on seed as the main source of planting material for propagating the cowpea lines.

Key words: Vigna unguiculata; growth; yield; proximate composition and productivity
Primerjalna analiza rasti, pridelka in kakovosti linij kitajske vinje (Vigna unguiculata L. (Walp.)) razmnoženih s semeni in stebelnimi potakjenci

Izvleček: V raziskavi je bil izveden poljski poskus za ovrednotenje in primerjavo učinkov sajenja s semeni in stebelnimi potakjenci dveh linij kitajske vinje (IT07K-243-1-2 and IT07K-298-15). Podatki ocene so bili podvrženi študentskemu t- testu, da bi ugotovili značilne učinke dveh metod razmnoževanja na ravni $p \leq 0,05$. Rezultati so pokazali, da so bili rastni parametri kot so višina rastlin, število listov, listna površina, nadzemna suha masa, indeks listne površine, razmerje med listi in površino tal, relativna prirast, neto asimilacija in rast pridelka značilno večji pri razmnoževanju s semeni v primerjavi s stebelnimi potakjenci. Komponente pridelka kot so število zrelih strokov na rastlino, masa strokov na rastlino, dolžina strokov, obseg strokov, polnjenje strokov, masa 100 semen, masa semen na rastlino, poprečno število semen na strok, žetveni indeks in pridelek strokov na kvadratni meter so imele podoben vzorec kot je bil zabeležen pri rastnih parametrih. Potencial kalitve pridobljenih semen kot tudi njihova vitalnost sta bila boljša pri semenih sejanih rastlin kot pri tistih iz potaknjencev. Razlika $\mathrm{v}$ različicah je pokazala, da je imela linija IT07K-298-15 večjo rast, večji pridelek in potencial kalitve kot linija IT07K-243-1-2, a je bila vsebnost beljakovin, maščob in ogljikovih hidratov pri slednji večja od normale. Na osnovi raziskave lahko zaključimo, da so imele rastline vzogojene iz semen večjo produktivnost. Kljub temu pa lahko vzpodbujamo vzgojo rastlin iz stebelnih potakjencev zaradi neznačilnih razlik med nekaterimi zgoraj naštetimi parametri in $s$ tem zmanjšamo odvisnost od semen kot glavnega vira razmnoževalnega materiala kitajske vinje.

Ključne besede: Vigna unguiculata; rast; pridelek; sestavine pridelka in produktivnost

\footnotetext{
1 University of Ilorin, Department of Plant Biology, Ilorin Nigeria

2 King Abdulaziz University, Faculty of Science, Department of Biological Sciences, Jeddah, Saudi Arabia

3 Federal University Dutsin-Ma, Faculty of Life Sciences, Department of Biological Sciences, Katsina State, Nigeria

4 Corresponding author, e-mail: asabdulbaki@fudutsinma.edu,ng
} 


\section{INTRODUCTION}

Cowpea (Vigna unguiculata (L.) Walp.) is of great importance both as staple and fodder crop and it is also used as cover crop to prevent soil erosion and desertification (Singh and Ntare, 1985). Cowpea constitutes a valuable source of protein as well as rich amino acid profile (Ayodele and Yalwa, 2004) and it is one of the widely cultivated leguminous crops in the savannah region of West Africa (Steele, 1996). Cowpea is a dicotyledonous species belonging to the order Fabales, family Fabaceae, sub-family Faboideae, tribe Phaseoleae, sub-tribe Phaseolinae, and genus Vigna (Singh, 1993; Padulosi and Ng, 2006). Like other legumes, cowpea forms a symbiotic relationship with a specific group of soil bacteria (Rhizobium) which makes atmospheric nitrogen available to the plant through nitrogen fixation (Tutiana et al., 2006).

Cowpea is usually propagated by seeds, however it can be propagated vegetatively using stem cuttings. An advancement in this area has been achieved through in vitro micropropagation through organogenesis and embryogenesis. Plant cuttings are segmented parts of plant organs that are used in vegetative propagation. Just like other vegetative propagation methods, the use of cuttings allows the production of clones. When mutations are neglected, clonally propagated plants can be considered as genetically identical to the parental plants. For crops that can be easily propagated by cuttings, this method has numerous advantages. Many new plants can be produced in a limited space from a few stock plants. It is simple and can be easily applied without special techniques such as grafting or budding. It is rapid because there is no need to produce rootstocks. It is also advantageous where a plant does not produce seeds or the seeds are sterile, or whenever seeds are not available (Bareja, 2010).

Over the last two decades, the International Institute of Tropical Agriculture (IITA) has made significant advances in improving the productivity of cowpea in sub-Saharan Africa. A number of varieties have been developed combining diverse plant types, different maturity periods, and resistance to several diseases, insect pests, and parasitic weeds, and possessing other good agronomic traits (Singh et al., 1997). These efforts could become irrelevant where there is paucity of seeds of several cowpea lines released by IITA. Another way to complement the effort of IITA is to try how these cowpea lines will perform when regenerated via vegetative propagation using stem cuttings which is an uncommon practice but can be an effective means of propagation when properly managed. It is this gap in knowledge this study aimed to address by comparing the growth, yield, proximate composition and germination potential of the harvested cowpea seeds propagated through seeds and stem cutting.

This study is therefore aimed at evaluating the regeneration and multiplication potential of cowpea using seed and stem (shoot) cuttings.

\section{MATERIALS AND METHODS}

\subsection{STUDY AREA AND SAMPLE COLLECTION}

The experiment was carried out at the Botanical Garden of University of Ilorin (Latitude $8^{\circ}, 29^{\prime} \mathrm{N}$ and Longitude $4^{\circ}, 35^{\prime} \mathrm{E}$ ) between August and December, 2016. Seeds of the two cowpea (IT07K-243-1-2 and IT07K-298-15) lines were collected from International Institute of Tropical Agriculture, Ibadan.

\subsection{SEED TREATMENT}

Seeds of the two cowpea lines ('Early; IT07K-243-1-2' and 'Dual-Purpose'; IT07K-298-15) were treated using Dress Force for residual treatment.

\subsection{EXPERIMENTAL DESIGN AND SEEDLING PRODUCTION}

The plot layout followed a split-plot arrangement where the variety constitutes the main plot and the method of propagation was the sub-plot. The two methods of propagation within the sub-plots followed complete randomized block design with three replications. Plant to plant spacing and within row spacing were $0.3 \mathrm{~m}$ and $0.6 \mathrm{~m}$ respectively. Seeds of the two cowpea varieties obtained were group into lots $\mathrm{A}$ and B. Seeds of lot were planted and the emerged seedlings after four weeks were used as stock. From this stock, stem of $0.12 \mathrm{~m}$ in length was cut using sterile knife for planting. The seeds lot B in each variety were sown on the same day the vegetative propagation was carried out from the seedlings obtained from seeds lot A.

\subsection{SOIL ANALYSIS}

Soil samples were collected from different portions of the plot and subjected to standard soil tests to determine the physico-chemical properties. The organic carbon was determined using modified Walkley and Black wet oxidation method. The percent organic carbon was 
multiplied by 1.72 (Van Bemmelen factor) to get percent organic matter. Soil $\mathrm{pH}$ was determined by the use of a pH meter. The modified Kjeldahl method was used to determine total nitrogen. Available phosphorus was determined by the Bray- 1 test method with dilute acid fluoride as the extractor. The exchangeable base cations were extracted using ammonium acetate at $\mathrm{pH}$ 7.0. Calcium and magnesium were determined using the ethylene diamine tetra acetic acid (EDTA) titration method while potassium and sodium were determined by the flame photometer method.

\subsection{MORPHOLOGICAL GROWTH CHARACTERS}

Parameters such as plant height, number of leaves, stem girth, root and shoot lengths and leaf area were measured. The leaf area was measured using: Leaf area $(\mathrm{LA})=0.75 \times(\mathrm{L} \times \mathrm{B})$ where 0.75 is the correlation factor (Abayomi and Adedoyin, 2004).

\subsection{DRY MATTER PRODUCTION}

After documenting the morphological growth parameters mentioned above, the plants were washed in running water after discarding the roots. Then, the above-ground plant parts in each experimental plot were packed in a polythene bags. Thereafter, these plants were oven dried at $75{ }^{\circ} \mathrm{C}$ to constant mass and the above-ground dry mass was then measured using MP1001 Electronic Balance with precision to 0.1g.

\subsection{PHYSIOLOGICAL GROWTH CHARACTERS}

Physiological growth parameters such as leaf area ratio (LAR), 1 area index (LAI), net assimilation rate ( NAR), crop growth rate (CGR) and relative growth rate (RGR) were measured as secondary data from aboveground-dry mass and leaf area. The formulae of the various growth analysis components were as follows

$$
\begin{aligned}
& L A R=\frac{\text { Leaf area }\left(\mathrm{m}^{2}\right)}{\text { Above-ground dry mass }(\mathrm{g})} \\
& \text { LAI }=\frac{\text { Leaf areaper plant }\left(\mathrm{m}^{2}\right)}{\text { Area of canopy of plant }\left(\mathrm{m}^{2}\right)}
\end{aligned}
$$

of Watson (1952) as adopted by El. Naim et al. (2011) and Olayinka and Etejere (2015).

$$
\mathrm{NAR}=\frac{\mathrm{W} 2-\mathrm{W} 1(\mathrm{Log} / \mathrm{eL} 2-\mathrm{Log} \mathrm{eL} 1)}{\mathrm{L} 2-\mathrm{L} 1(\mathrm{t} 2-\mathrm{t} 1)}
$$

$\mathrm{g} \mathrm{m}^{-2}$ day $^{-1}$ described by Evans (1972) and Abayomi and Adedoyin (2004)

Crop growth rate $=$ net assimilation rate $(\mathrm{NAR})$ $\times$ leaf area index (LAI) $\mathrm{g} \mathrm{m}^{-2}$ day $^{-1}$ described by Evans (1972) and Causton and Venus, (1981).

Relative growth rate:

$$
(\mathrm{RGR})=\frac{\mathrm{Log} \text { eW2 }- \text { Log eW1 }}{\mathrm{t} 1-\mathrm{t} 2}(\mathrm{~g} g-1 \text { day }-1)
$$

Chlorophyll content was quantified according to the method described by Jnandabhiram and Sailen (2012).

\subsection{PROXIMATE COMPOSITION}

Proximate parameters such as moisture, ash, fibre, fat, protein and carbohydrate by difference of the airdry harvested seeds from the two cowpea lines were determined following the methods described by AOAC (2000).

\section{RESULTS AND DISCUSSION}

\subsection{SOIL CHARACTERISTICS}

The initial pre-planting soil properties of the experimental site show that the soil is marginally fertile which implies that the soil is low in $\mathrm{N}$ content, organic matter, available phosphorus exchangeable bases and exchangeable cations following the soil quality ranges of ederal Ministry of Agriculture and Natural Resources (FMANR, 1990). This further implies that the soil is poor in nutrients and of low productivity. The observed 6.80 value of the $\mathrm{pH}$ of the soil indicates that the soil is slightly acidic and this can be attributed to the high rainfall prevalent in the area at the time of collection. Rainfall leads to leaching of the basic cations from the surface area of the soil (Agbogidi and Egho, 2012). The low organic matter content and total nitrogen could be attributed to the effects of soil erosion, leaching and bush burning predominant in the study area. Similarly, the low exchangeable cations may be due to the low clay activity and low organic content (0.48) of the soil. The CEC was low $\left(6.76 \mathrm{cmol} \mathrm{kg}^{-1}\right)$ while the base saturation (67.92\%) which provides an index of soil weathering, indicates that the site has moderate fertility status. Savanna soils are inherently low in nutrients particularly nitrogen and phosphorus (Haruna et al., 2011; Haruna and Usman, 2013). 
Table 1: Physical and chemical properties of the experimental surface soil $(0-15 \mathrm{~cm})$ before planting in 2016

Soil characteristics

Physical properties Particle sizes

Percent distribution (\%)

Sand $\quad 86.4$

Silt

8.9

Clay

4.7

Textural Class

Loamy sand

Chemical properties

$\begin{array}{ll}\mathrm{pH}\left(\mathrm{H}_{2} \mathrm{O}\right) & 6.80 \\ \mathrm{OC} & 0.28 \\ \mathrm{OM} & 0.48 \\ \mathrm{TKN} & 0.16\end{array}$

$\mathrm{AP}\left(\mathrm{mg} \mathrm{kg}^{-1}\right) \quad 3.87$

$\mathrm{Ca}\left(\mathrm{cmol} \mathrm{kg}^{-1}\right) \quad 5.83$

$\mathrm{Mg}\left(\mathrm{cmol} \mathrm{kg}^{-1}\right) \quad 0.62$

$\mathrm{K}\left(\mathrm{cmol} \mathrm{kg}^{-1}\right) \quad 0.11$

$\mathrm{Na}\left(\mathrm{cmol} \mathrm{kg}^{-1}\right) \quad 0.15$

$\mathrm{H}+\mathrm{Al}\left(\mathrm{cmol} \mathrm{kg}^{-1}\right) \quad 0.05$

$\operatorname{ECEC~}\left(\mathrm{cmol} \mathrm{kg}^{-1}\right) \quad 6.76$

Base saturation (\%) $\quad 67.92$

$\mathrm{OC}=$ Organic carbon; $\mathrm{OM}=$ Organic matter $; \mathrm{TKN}=$ Total Kjeldah Nitrogen, $\mathrm{AP}=$ Available Phosphorus, $\mathrm{Ca}=\mathrm{Calcium} ; \mathrm{Mg}=$ Magnesium $; \mathrm{K}=$ Potassium $; \mathrm{Na}=$ Sodium, $\mathrm{H}+\mathrm{Al}=$ Exchangeable Acidity, and ECEC = Effective Cation Exchangeable Capacity.

\subsection{GROWTH RESPONSE}

The growth performance in terms of plant height, number of leaves, stem girth and leaf area were significantly higher in all the seed-propagated plants (Figures $1,2,3$ and 4). The high expression of these growth attributes in all the seed propagated cowpea, compared to those propagated by stem cuttings could be due to differences in distribution of endogenous hormones. According to $\mathrm{Li}$ et al. 2011, morphogenesis of shoot is highly influenced by the plant hormones. In both lines, $V$. unguiculata propagated by stem cuttings followed the same growth pattern as those propagated by seed, but maintained lower magnitude from 2 weeks after planting (WAP) until final date of sampling (10 WAP). A contrasting pattern was observed only in the plant height of line IT07K-243-1-2 where the stem propagated plants showed higher magnitude. IT07K-243-1-2 recorded higher peak than IT07K-298-15 showing genotypic variation which is agreed with the findings of Agbogidi and Egho, (2012), in evaluation of cowpea varieties in agro-ecological environment. Reduced shoot development in the stem propagated $V$. unguiculata is as a result of the plants committing their carbohydrate to rooting rather than photosynthesis.

Root characteristics (root length and root-shoot ratio) significantly differed $(p<0.05)$ with respect to methods of propagation and genotype (Figures 5 and 6). In both lines, greater root length was recorded by the seed propagated $V$. unguiculata as compared to those regenerated through stem cuttings. This could be attributed to differing concentrations of the endogenous growth regulators. Li et al. (2011) in their review on regeneration in cowpea inferred that higher ratio of auxin to cytokinin concentration induces rooting of explants (stem cuttings) in a regeneration system. Rootshoot ratio which refers to the ratio of the root mass to mass of the shoot (Harris, 1992) showed significance difference between the propagation methods. In both lines, the stem propagated cowpea recorded higher ratios especially at 3 and 6 weeks after planting, an indication of acclimatization after transplanting.

This also showed that cowpea propagated by stem cutting absorbed less nutrient at the time when increase in rooting volume was predominant. According to Harris (1992), factors which improve growing conditions cause reduction in root-shoot ratio.

\subsection{DRY MATTER PRODUCTION}

Dry matter production of the two cowpea lines tested differed significantly with respect to methods of propagation (Figure 5). Seed propagated cowpea accumulated more dry matter and this can be an indication of the unpronounced growth observed in the stem propagated plants. However, the same pattern of increase was observed for both methods and genotypic difference was evident since line IT07K-243-1-2 recorded a greater peak for seed while IT07K-298-15 recorded greater peak for stem propagated. The similar pattern of increase in dry matter (above-ground dry mass) with time, agreed with the studies of AddoQuaye et al. (2011) on dry matter production of three varieties of cowpea in two agro-ecological zones.

Leaf area ratio increased in magnitude followed by a decrease in line IT07K-243-1-2, a contrasting pattern was observed in IT07K-298-15 which decreased linearly until the final date of sampling, regardless of the methods of propagation (Figure 6). The seed propagated plants recorded higher peak than the stem propagated plants, an estimate of the level of reproductive strategy based on light and moisture absorbed by the plants. The lower magnitude recorded by the stem propagated of $V$. unguiculata could result from efforts 


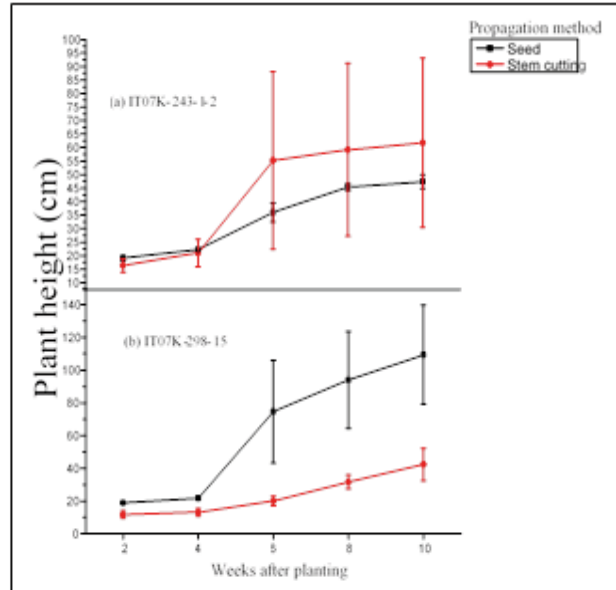

Figure 1: Plant height of $V$. unguiculata (a) IT07K-243-12 and (b) IT07K-298-15 as affected by different propagation methods, Vertical bars represent standard errors of mean (SEM).

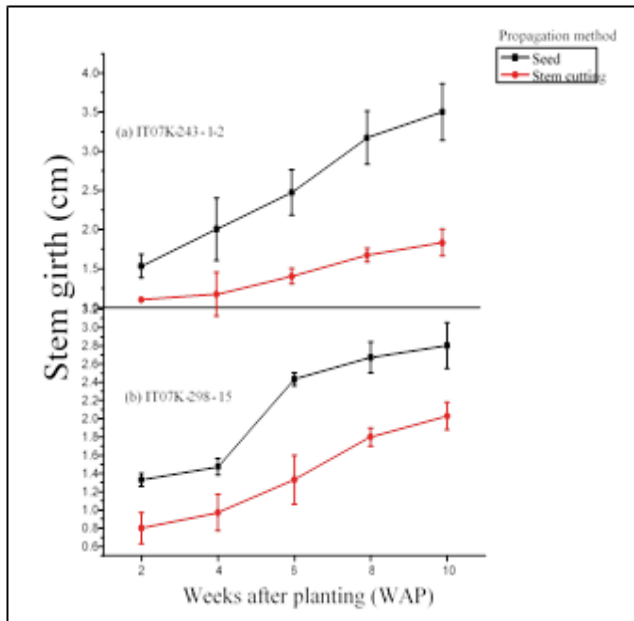

Figure 3: Stem girth of $V$. unguiculatg as affected by different propagation m ethods in (a) IT07K-243-1-2 and (b) IT07K-298-15. Vertical bars represent standard errors of m ean (SEM).

of the plant to conserve the acquired resources, according to Marron et al. (2003).

Relative growth rate, which is the rate of increase in dry mass already accumulated per unit time, was significantly affected by methods of propagation and genotype (Figure 9). There was no significant difference in RGR between the two methods of propagation in line IT07K-243-1-2 as they also followed similar pattern. Seed propagated plants recorded higher peak. RGR in IT07K-298-15 statistically differed with respect to the propagation methods with the stem propagated plants recording the higher peak. The difference in RGR further depicts the varietal differences.

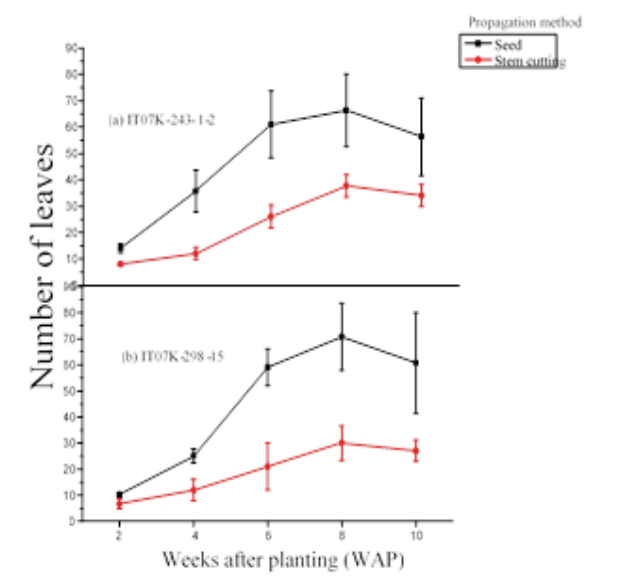

Figure 2: Num ber of leaves of $V$. unguiculatg as affected by different propagation m ethods in (a) IT07K-243-1-2 and (b) IT07K-298-15. Vertical bars represent standard errors of mean (SEM).

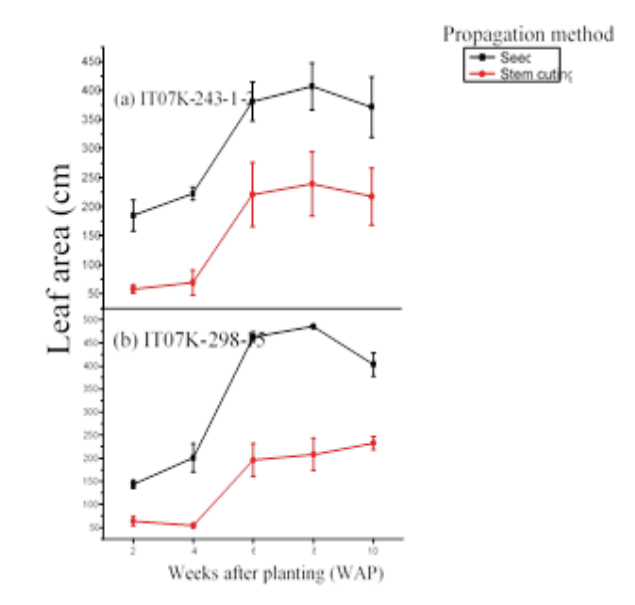

Figure 4: Leaf area of $V$. unguiculatg a s affected by different propagation methods in (a) IT07K-243-1-2 and (b) IT07K298-15. Vertical bars represent standard errors of mean (SEM).

Leaf area index, a descriptor of the size of the assimilatory apparatus of the plant stand, is said to be the primary factor that determines the rate of dry matter production in a stand. It also reflects differences in productive efficiency between crop varieties (Kvet et al., 1971). Leaf area index was significantly affected by the methods of propagation and genotype. Regardless of the propagation method and line, leaf area index was increasing with time until 63 days and then decreased until 84 days (Figure 10). This agreed with the pattern in leaf area index as reported by Addo-Quaye et al. (2011). For the seed propagated cowpea, IT07K-298-15 showed greater productive efficiency while IT07K-243-1-2 


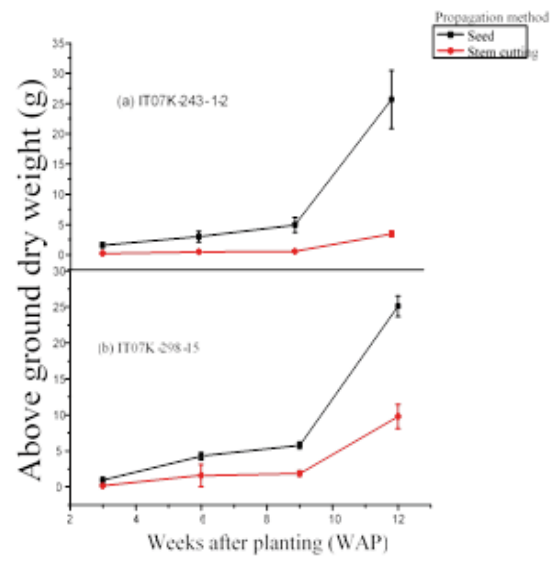

Figure 5: Above ground mass of $V$. unguiculato as affected by different propagation m ethods in (a) IT07K243-1-2 (b) IT07K-298-15. Vertical bars represent standard errors of m ean (SEM).

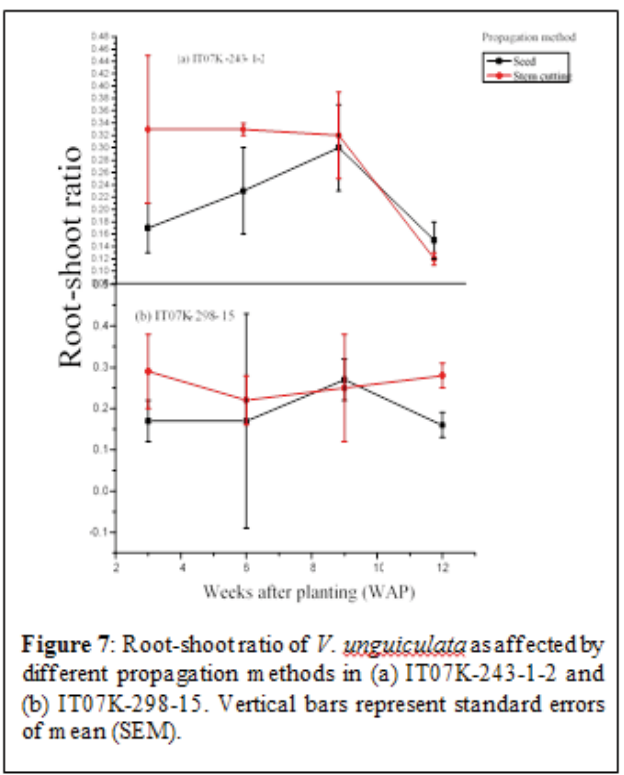

showed greater efficiency for those propagated by stem cutting, another indication of varietal difference. The larger area covered by the seed propagated plants contributed to the large leaf area indices produced. Similarly, Terao et al. (1995) found that cowpea varieties with more spread collected more light than those with lesser spread and consequently produced more leaves, which resulted in larger leaf area indices. The pattern of leaf area development in this study is similar to those reported by Olayinka and Etejere (2015).

Net assimilation rate, which is the rate of dry mass increase per unit leaf area per unit time, showed significant difference between the methods at sampling inter-

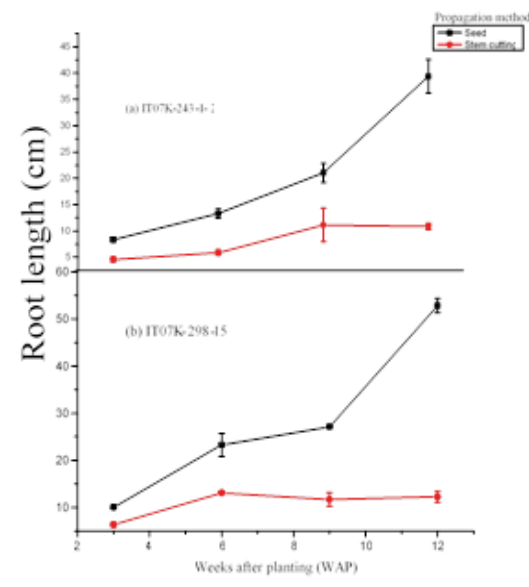

Figure 6: Root length of $V$. unguiculata as affected by different propagation methods in (a) IT07K-243-1-2 and (b) IT07K-298-15. Vertical bars represent standard errors of m ean (SEM).

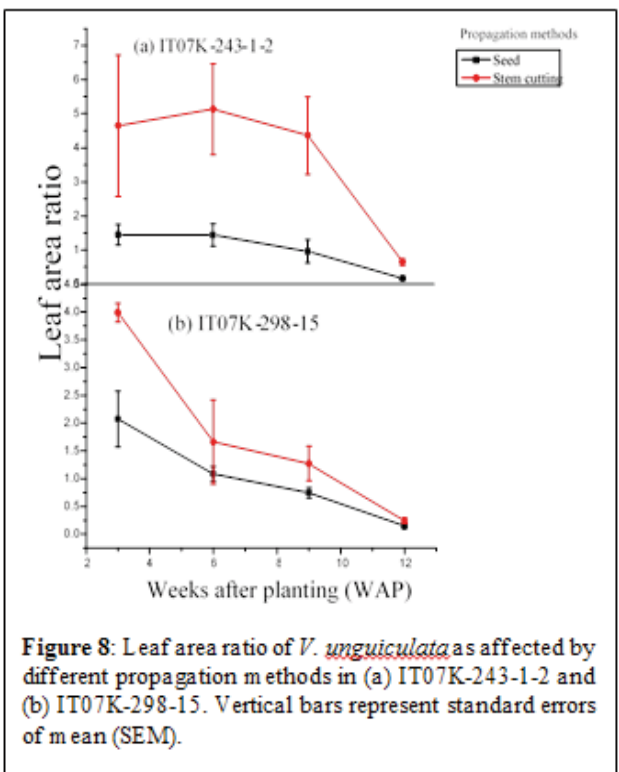

val of 63-84 days in IT07K-243-1-2 and 42-63 days in IT07K-298-15 (Figure 11). Differing pattern of increase in NAR agreed with those reported by Addo-Quaye et al. (2011). Regardless of the genotype, the seed propagated plants recorded greater values of NAR, an indication that their leaves are more efficient in producing dry matter than those regenerated by stem cutting.

Crop growth rate, an index of agricultural productivity significantly differed between the methods of propagated in the two cowpea lines tested (Figure 12). A similar pattern of slight decrease followed by rapid increase in CGR was observed in both lines. 


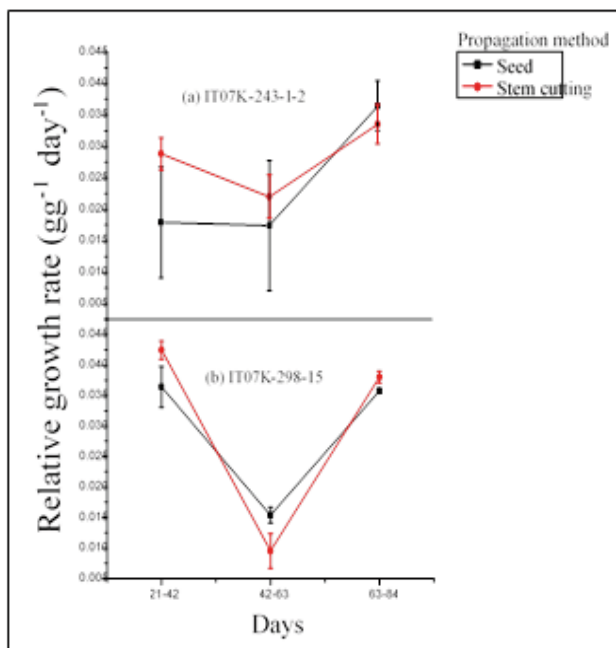

Figure 9: Relative growth rate of $V$. unguiculata as affected by different propagation m ethods in (a) IT07K243-1-2 and (b) IT07K-298-15. Vertical bars represent standard errors of m ean (SEM).

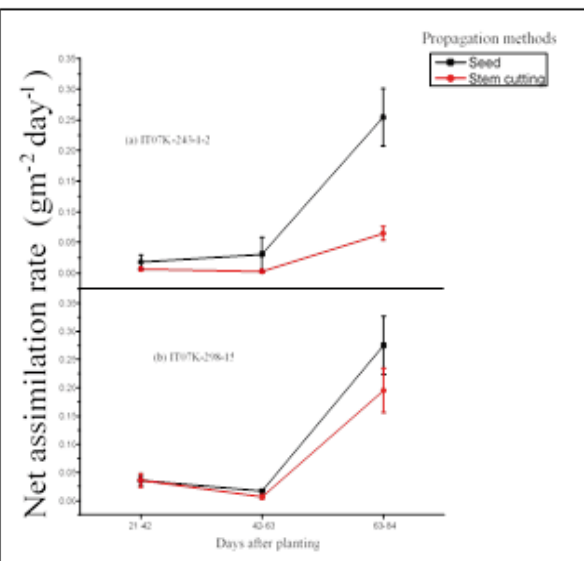

Figure 11: Net assimilation rate of $V$. unguiculata as affected by different propagation methods in (a) IT07K243-1-2 and (b) IT07K-298-15. Vertical bars represent standard errors of m ean (SEM).

Cowpea propagated by seed showed greater CGR than those propagated by stem cutting. Since CGR measured the accumulation of dry matter per unit time, it was, therefore a reasonable approximation of the canopy photosynthetic rate per unit ground area (Clawson et. al., 1986). The significantly higher CGR values of IT07K-243-1-2 as against IT07K-298-15, suggested that the stands of this line produced more dry matter per unit ground area than IT07K-298-15 in spite of its lower LAI and NAR. Results of crop growth rate in this study aligned with the report of Addo-Quaye et al. (2011) and Olayinka and Etejere (2015).

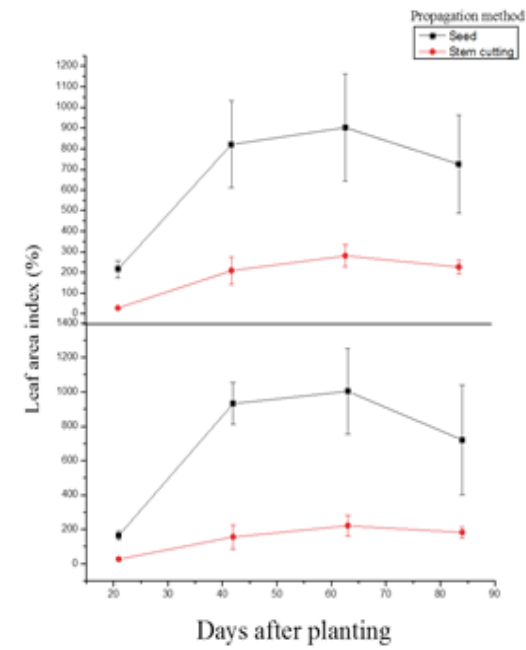

Figure 10: Leaf area index of $V$. unguiculato as affected by different propagation methods in (a) IT07K-243-1-2 and (b) IT07K-298-15. Vertical bars represent standard errors of m ean (SEM)

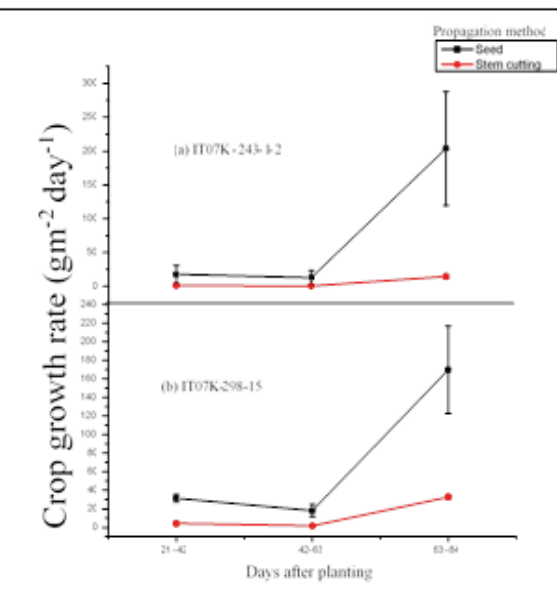

Figure 12: Crop growth rate of $V$. unguiculata as affected by different propagation methods in (a) IT07K-243-1-2 and (b) IT07K-298-15. Vertical bars represent standard errors of m ean (SEM).

\subsection{CHLOROPHYLL CONTENT}

The effects of methods of propagation and genotype showed significance on the chlorophyll content of V. unguiculata (Figures 13,14 and 15). Similar trend in chlorophyll content was observed in the methods within each line of cowpea. Between the lines, different patterns were observed in chlorophyll a, b and total chlorophyll, an implication of the effect of genotype. Chlorophyll- $a$ and Chlorophyll- $b$ attributes to the accumulation of solutes in the cell sap through passive accumulation resulting from reduced cell size (Morgan, 1984) which significantly does osmotic adjustment 


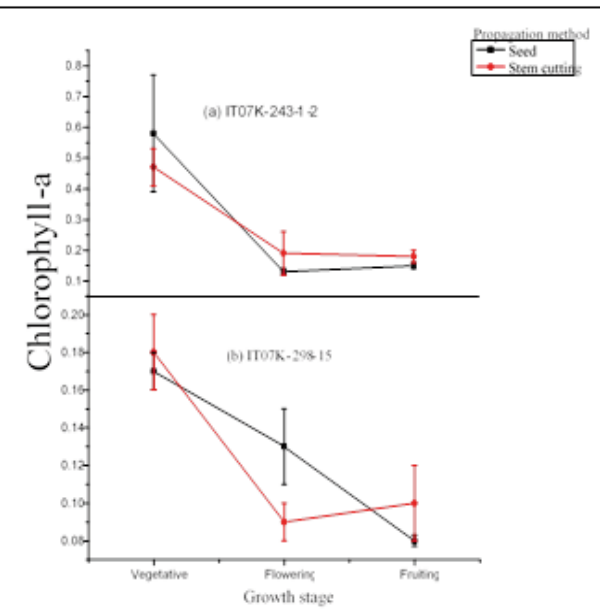

Figure 13: Chlorophyll-a content of $V$. unguiculata as affected by different propagation methods in (a) IT07K243-1-2 and (b) IT07K-298-15. Vertical bars represent standard errors of m ean (SEM).

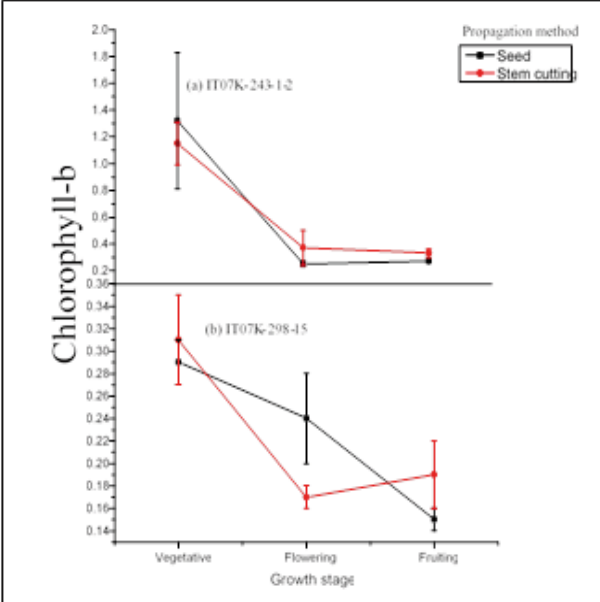

Figure 14: Chlorophyll-b content of $V$. unguiculata as affected by different propagation methods in (a) IT07K243-1-2 (b) IT07K-298-15. Vertical bars represent standard errors of m ean (SEM).
$(\Delta \psi \pi)$. Non-stomatal restrictions on $\mathrm{CO}_{2}$ assimilation can be effectively assessed through measuring chlorophyll based parameters. Energy status of the chloroplast increases as a consequence of increased amount of total chlorophyll and Chl $a$ and Chlb (Ranjbarfordoei et al., 2000).

\subsubsection{Yield and yield components}

The results of the yield components and yield such as number of matured pod per plant, pod weight per plant, pod length, pod circumference, pod filling, hundred (100) seed weight, seed weight per plant, average number of seed per pod, harvest index and pod yield per metre square followed similar pattern as recorded for growth characters.

In both lines, relatively low yield was recorded, regardless of the method of propagation. This could be as a result of low phosphorus content of the soil. Phosphorus, one of the most needed elements for crop production is critical to cowpea yield (Haruna and Usman, 2013). This is because it is reported to stimulate growth, initiate nodule formation and also influences the efficiency of rhizobium-legume symbiosis (Haruna and Aliyu, 2011). All growing plants require phosphorus for growth and development in significantly larger amount. 
Table 2: Reproductive character and yield components of Vigna unguiculata lines as influenced by different propagation methods

\begin{tabular}{llllllll}
\hline \multirow{2}{*}{ Lines } & & \multicolumn{2}{l}{$\begin{array}{l}\text { No of matured Pod mass per } \\
\text { pod per plant length }\end{array}$} & \multicolumn{2}{l}{$\begin{array}{l}\text { Pod circumfer- } \\
\text { ence }(\mathrm{cm})\end{array}$} & $\begin{array}{l}\text { Number of days } \\
(\mathrm{cm})\end{array}$ & $\begin{array}{l}\text { Pod filling } \\
\text { to 50 \% flowering }\end{array}$ \\
\hline IT07K-243-1-2 & Seed & $18.67+1.20 \mathrm{a}$ & $15.87+0.12 \mathrm{a}$ & $17.62+1.00 \mathrm{a}$ & $2.72+0.13 \mathrm{a}$ & $0.44+0.04 \mathrm{a}$ & $41.33+1.86 \mathrm{a}$ \\
& Stem cutting & $6.67+0.88 \mathrm{~b}$ & $7.02+0.81 \mathrm{~b}$ & $13.88+0.48 \mathrm{~b}$ & $2.21+0.16 \mathrm{a}$ & $0.28+0.04 \mathrm{a}$ & $32.00+1.16 \mathrm{a}$ \\
& P-value & 0.016 & 0.006 & 0.022 & 0.103 & 0.137 & 0.088 \\
IT07K-298-15 & Seed & $16.33+0.88 \mathrm{a}$ & $17.32+0.44 \mathrm{a}$ & $17.41+0.78 \mathrm{a}$ & $2.70+0.17 \mathrm{a}$ & $0.36+0.03 \mathrm{a}$ & $48.00+1.16 \mathrm{a}$ \\
& Stem cutting & $6.33+0.88 \mathrm{~b}$ & $7.33+0.48 \mathrm{~b}$ & $12.26+1.21 \mathrm{a}$ & $1.87+0.11 \mathrm{a}$ & $0.28+0.06 \mathrm{a}$ & $55.33+1.20 \mathrm{~b}$ \\
& P-value & 0.003 & 0.008 & 0.100 & 0.087 & 0.145 & 0.037 \\
Mean & IT07K-243-1-2 & $12.00+1.53$ & $8.84+0.71$ & $3.74+0.56$ & $0.51+0.18$ & $0.15+0.06$ & $9.33+2.96$ \\
& IT07K-298-15 & $10.00+0.58$ & $9.98+0.92$ & $5.16+1.77$ & $0.83+0.26$ & $0.80+0.03$ & $7.33+1.45$ \\
& P-value & 0.058 & 0.039 & 0.101 & 0.149 & 0.382 & 0.076 \\
\hline
\end{tabular}

Within variety along the column means followed by the same superscript are not significantly different at $p<0.05$

Table 3: Yield of V. unguiculata lines as influenced by different propagation methods and genotype

\begin{tabular}{llllllll}
\hline \multirow{2}{*}{ Lines } & $\begin{array}{l}\text { Methods of } \\
\text { propagation }\end{array}$ & \multicolumn{2}{l}{$\begin{array}{l}\text { Number of seed 100 seed mass } \\
\text { per plant }\end{array}$} & $\begin{array}{l}\text { Seed massper } \\
\text { plant }(\mathrm{g})\end{array}$ & $\begin{array}{l}\text { Average No of } \\
\text { seed per pod }\end{array}$ & $\begin{array}{l}\text { Harvest index } \\
\text { (g m-2) }\end{array}$ \\
\hline IT07K-243-1-2 & Seed & $55.33+6.98 \mathrm{a}$ & $17.47+0.46 \mathrm{a}$ & $9.02+1.02 \mathrm{a}$ & $7.93+0.31 \mathrm{a}$ & $0.24+0.05 \mathrm{a}$ & $40.10+4.52 \mathrm{a}$ \\
& Stem cutting & $24.67+0.88 \mathrm{a}$ & $11.20+0.76 \mathrm{~b}$ & $2.29+0.14 \mathrm{~b}$ & $4.31+0.68 \mathrm{~b}$ & $0.38+0.04 \mathrm{a}$ & $10.18+0.61 \mathrm{~b}$ \\
& P-value & 0.060 & 0.036 & 0.028 & 0.035 & 0.243 & 0.028 \\
IT07K-298-15 & Seed & $49.00+3.46 \mathrm{a}$ & $14.84+0.29 \mathrm{a}$ & $8.04+0.51 \mathrm{a}$ & $6.44+0.87 \mathrm{a}$ & $0.22+0.00 \mathrm{a}$ & $35.73+2.28 \mathrm{a}$ \\
& Stem cutting & $18.67+1.20$ & $12.02+0.33$ & $3.03+0.23$ & $3.78+0.22$ & $0.20+0.02$ & $13.45+1.01$ \\
& P-value & $0.012 \mathrm{~b}$ & $0.010 \mathrm{~b}$ & $0.006 \mathrm{~b}$ & $0.094 \mathrm{a}$ & $0.462 \mathrm{a}$ & $0.006 \mathrm{~b}$ \\
Means & IT07K-243-1-2 & $40.00+3.93$ & $14.34+0.61$ & $5.66+0.58$ & $6.12+0.49$ & $0.31+0.05$ & $25.14+2.57$ \\
& IT07K-298-15 & $33.84+2.33$ & $13.43+0.31$ & $5.54+0.37$ & $4.51+0.55$ & $0.21+0.01$ & $24.59+1.65$ \\
P-value & & 0.053 & 0.021 & 0.007 & 0.096 & 0.121 & 0.007 \\
\hline
\end{tabular}

Within variety along the column means followed by the same superscript are not significantly different at $p<0.05$.

\subsection{GERMINATION POTENTIAL}

The results indicated that the two methods of propagation could be said to appropriate for raising the two cowpea lines studied. However, germinability in terms of percentage germination, speed of germination seedling vigour in both cowpea lines were generally better when raised from seed planting than those obtained from stem cutting. The varietal effect showed that line IT07K-298-15 had better performance than line IT07K-243-1-2. Differential germination potential between the two lines can be attributed to the different genetic make-up. This is in agreement with results of germination potential of several cultivars of groundnut (Ahmed et al., 2017).

\subsection{PROXIMATE COMPOSITION}

Proximate components were significantly $(p \leq 0.05)$ af- fected by propagation methods (Table 5) except for protein recorded in IT07K-298-15. Statistically similar values were recorded with respect to genotypes. Regardless of the propagation methods, IT07K-243-1-2 recorded higher protein, fat and carbohydrate while IT07K-298-15 recorded higher moisture ash and fibre contents. Protein content recorded in both lines was within the range of values (20-27 \%) reported by Duke (1981) and Longe (1980).

\section{CONCLUSION}

Results of the present study show that seed planting is still better method of propagation. However, stem could still be encouraged on account of non-significant difference in some of the aforementioned attributes, thereby limiting over-reliance on seed as source of material for propagating the cowpea lines. Concerted 
Table 4: Germination potential and seedling growth of the seeds harvested from two cowpea lines grown under different methods of propagation

\begin{tabular}{|c|c|c|c|c|c|c|}
\hline Lines & $\begin{array}{l}\text { Methods of prop } \\
\text { gation }\end{array}$ & $\begin{array}{l}\text { - Germination } \\
(\%)\end{array}$ & $\mathrm{n}$ & Seedling Vigour & $\begin{array}{l}\text { Shoot length } \\
(\mathrm{mm})\end{array}$ & $\begin{array}{l}\text { Seminal root } \\
\text { length }(\mathrm{mm})\end{array}$ \\
\hline \multirow[t]{3}{*}{ IT07K-243-1-2 } & Seed & $20.00 \pm 5.77^{a}$ & $0.40 \pm 0.0 .12^{\mathrm{a}}$ & $590.0 \pm 181.9^{a}$ & $12.7 \pm 0.15^{a}$ & $17.0 \pm 0.06^{\mathrm{a}}$ \\
\hline & Stem Cutting & $13.33 \pm 3.33^{\mathrm{a}}$ & $0.27 \pm 0.07^{\mathrm{a}}$ & $393.33 \pm 83.38^{\mathrm{a}}$ & $13.5 \pm 0.76^{a}$ & $16.8 \pm 0.02^{a}$ \\
\hline & P-value & 0.529 & 0.529 & 0.531 & 0.406 & 0.742 \\
\hline \multirow[t]{3}{*}{ IT07K-298-15 } & Seed & $63.33 \pm 17.64^{\mathrm{a}}$ & $4.07 \pm 0.98^{\mathrm{a}}$ & $2071.70 \pm 578.62^{a}$ & $13.4 \pm 0.03^{a}$ & $19.3 \pm 0.33^{\mathrm{a}}$ \\
\hline & Stem cutting & $56.67 \pm 17.64^{\mathrm{a}}$ & $3.67 \pm 1.71^{\mathrm{a}}$ & $1802.00 \pm 571.95^{\mathrm{a}}$ & $13.4 \pm 0.09^{a}$ & $18.5 \pm 0.14^{\mathrm{a}}$ \\
\hline & P-value & 0.826 & 0.868 & 0.777 & 0.866 & 0.668 \\
\hline \multirow[t]{2}{*}{ Lines Mean } & IT07K-243-1-2 & $16.67 \pm 4.50$ & $0.34 \pm 0.041$ & $491.67 \pm 132.65$ & $12.9 \pm 0.46$ & $16.9 \pm 0.04$ \\
\hline & IT07K-298-15 & $60.00 \pm 17.64$ & $3.87 \pm 1.35$ & $1936.85 \pm 57529$ & $13.4 \pm 0.06$ & $18.9 \pm 0.24$ \\
\hline $\mathrm{p}$-value & & $<0.001$ & 0.300 & 0.099 & 0.500 & 0.344 \\
\hline
\end{tabular}

Within variety along the column means followed by the same superscript are not significantly different at $p<0.05$.

Table 5: Proximate composition of V. unguiculata lines as influenced by different propagation methods and genotype

\begin{tabular}{|c|c|c|c|c|c|c|c|}
\hline Lines & $\begin{array}{l}\text { Propagation } \\
\text { methods }\end{array}$ & Moisture & Ash & Fibre & Protein & Fat & $\begin{array}{l}\text { Carbohy- } \\
\text { drate }\end{array}$ \\
\hline \multirow[t]{3}{*}{ IT07K-243-1-2 } & Seed & $16.42 \pm 0.51 \mathrm{a}$ & $0.95 \pm 0.01 \mathrm{a}$ & $3.99 \pm 0.07 \mathrm{a}$ & $21.25 \pm 0.15 \mathrm{a}$ & $5.05 \pm 0.09 \mathrm{a}$ & $52.34 \pm 0.35 \mathrm{a}$ \\
\hline & Stem cutting & $14.63 \pm 0.17 \mathrm{a}$ & $0.69 \pm 0.23 \mathrm{a}$ & $3.12 \pm 0.22 \mathrm{a}$ & $21.25 \pm 0.15 \mathrm{a}$ & $4.19 \pm 0.15 \mathrm{a}$ & $56.13 \pm 0.76 \mathrm{a}$ \\
\hline & $\mathrm{P}$-value & 0.063 & 0.729 & 0.135 & 0.064 & 0.684 & 0.861 \\
\hline \multirow[t]{3}{*}{ IT07K-298-15 } & Seed & $17.54 \pm 6.68 \mathrm{a}$ & $1.19 \pm 0.24 \mathrm{a}$ & $3.76 \pm 0.24 \mathrm{a}$ & $21.23 \pm 0.19 \mathrm{a}$ & $4.57 \pm 0.31 \mathrm{a}$ & $51.69 \pm 6.39 \mathrm{a}$ \\
\hline & Stem cutting & $13.91 \pm 1.63 \mathrm{a}$ & $1.09 \pm 0.32 \mathrm{a}$ & $3.52 \pm 0.19 \mathrm{a}$ & $21.24 \pm 0.18 b$ & $4.48 \pm 0.32 \mathrm{a}$ & $55.76 \pm 1.98 \mathrm{a}$ \\
\hline & $\mathrm{P}$-value & 0.293 & 0.244 & 0.848 & 0.022 & 0.662 & 0.406 \\
\hline \multirow[t]{2}{*}{ Means } & IT07K-243-1-2 & $15.52 \pm 0.89$ & $0.82 \pm 0.13$ & $3.55 \pm 0.44$ & $21.25 \pm 0.00$ & $4.62 \pm 0.43$ & $54.24 \pm 1.89$ \\
\hline & IT07K-298-15 & $15.73 \pm 1.81$ & $1.14 \pm 0.05$ & $3.64 \pm 0.12$ & $21.24 \pm 0.00$ & $4.53 \pm 0.05$ & $53.73 \pm 2.03$ \\
\hline $\mathrm{P}$-value & & 0.000 & 0.000 & 0.000 & 0.000 & 0.000 & 0.000 \\
\hline
\end{tabular}

Within variety along the column means followed by the same superscript are not significantly different at $p<0.05$.

efforts should be made to evaluate the effects of stem cutting method on the genetic variability of these cowpea lines.

\section{REFERENCES}

Abayomi, Y.A. and Adedoyin, G.A. (2004). Effects of planting dates and nitrogen fertilizer application on growth and yield of its contrasting genotypes of maize (Zea mays L.) I: leaf growth and its relationship with grain yield. Journal of Agricultural Research \& Development, 3, 83-97. https:// doi.org/10.4314/jard.v3i1.42215

Addo-Quaye, A.A., Darkwa, A.A. and Ampiah, M.K.P. (2011). Performance of three cowpea (Vigna unguiculata (L.) Walp) varieties in two agro-ecological zones of Central Region of Ghana I: Dry matter production and growth analysis. ARPN Journal of Agricultural and Biological Sciences, 6(2), 1-9.
Agbogidi, O.M. and Egho, E.O. (2012). Evaluation of eight varieties of cowpea (Vigna unguiculata (L). Walp) in Asaba agro-ecological environment, Delta State, Nigeria. European Journal of Sustainable Development, 1(2), 303-314.

Ahmed, O., Olayinka, B.U., Garuba, T., Ahmed, J. and Etejere, E.O. (2017). Germination of several cultivars of groundnut in relation to incidence of fungi. Science World Journal, 12(1), 38-41.

Ayodele, J. T. and Yalwa, I. R. (2004). Amino Acid composition of Vigna dekindtiana. Biological and Environmental Sciences Journal for the Tropics, 1(2), 120-126.

AOAC. (2000). Official method of analysis (17 ${ }^{\text {th }}$ Edition). Volume 1. Association of Official Analytical Chemists. Inc., Maryland, USA.

Bareja, B.G. (2010). The What, When and Why Of Using Plant Cuttings In Vegetative Propagation. Crops Review. Available at http://www.cropsreview.com/plant-cuttings.html. Causton, D.R. and Venus, J.C. (1981). The biometry of plant 
growth. London: Edward Arnold Center AgricSci (JIRCAS). Sayce, Devon, UK, pp. 1-12.

Clawson, K.L., Specht, J.E. and Blad, B.L. (1986). Growth analysis of soyabean isolines differing in pubescence density. Agronomy Journal, 78, 164-172. https://doi.org/10.2134/ag ronj1986.00021962007800010033x

Duke, J.A. (1981). Handbook of legumes of world economic importance. New York: Plenum Press. https://doi. org/10.1007/978-1-4684-8151-8

El-Naim, A.M., Eldouma, M.A., Ibrahim, E.A., Zaied, M.M.B. (2011). Influence of plant spacing and weeds on growth and yield of peanut (Arachis hypogaea L.) in rain-fed of Sudan. Advances in Life Sciences, 1(2), 45-48. https://doi. org/10.5923/j.als.20110102.08

Evans, G.C. (1972). The quantitative analysis of plant growth. Oxford: Blackwell Scientific Publications.

Harris, R.W. (1992). Root-shoot ratio. Journal of Arboriculture, $18(1), 39-42$.

Haruna, I.M., Aliyu, L., Olufajo, O.O. and Odion, E.C. (2011). Growth of sesame (Sesamum indicum L.) as influenced by poultry manure, nitrogen and phosphorus at Samaru, Nigeria. Am. Eurasian. Journal of Agriculture and Environmental Science, 4, 561-568. https://doi.org/10.3923/ ajcs.2013.209.215

Haruna, I.M. and Usman, A. (2013). Agronomic efficiency of cowpea varieties (Vigna unguiculata L. Walp.) under varying phosphorus rates in Lafia, Nassarawa State, Nigeria. Asian Journal of Crop Science, 5(2), 209-215.

Jnandabhiram, C. and Sailen, P.B. (2012).Water stress effects on leaf growth and chlorophyll content but not the grain yield in traditional rice (Oryza sativa Linn.) genotypes of Assam, India II. Protein and proline status in seedlings under PEG induced water stress. American Journal of Plant Sciences, 3, 971-980. https://doi.org/10.4236/ ajps.2012.37115

Kvet J., Ondok J.P., Necas J. and Jarvis P.G. (1971). Methods of growth analysis. In: Sestak, Z., Catsky, J. and Jarvis, P.G. (Eds.), Plant Photosynthetic Production: Manual of Methods. Dr W. Junk N.V., The Hague. pp. 343-391.

Li, X.M., Li, J. Li, M., Tang, Y., Li, X. and Chen, L. (2011). A review on regeneration of cowpea (Vigna unguiculata $\mathrm{L}$. Walp). Journal of Agricultural Science and Technology, 5(4), 525-532.

Longe, O.G. (1980). Carbohydrate composition of different varieties of cowpea (Vigna unguiculata). Food Chemistry,
6, 153-161. https://doi.org/10.1016/0308-8146(80)90031$\mathrm{X}$

Maroon, N., Dreyer, E., Boudouresque, E., Delay, D., petit, J.m., Delmotte, F.M. and Brignolas, F. (2003). Impact of successive drought and re-watering cycles on growth and specific leaf area of two Populus canadensis (Moench) clones. Tree Physiology, 23, 1225-1235. https://doi.org/10.1093/ treephys/23.18.1225

Morgan, J.M. (1984). Osmoregulation and water stress in higher plants. Annual. Review of Plant Physiology, 35, 299-319. https://doi.org/10.1146/annurev.pp.35.060184.001503

Olayinka, B.U. and Etejere, E.O. (2015). Growth analysis and yield of two varieties of groundnut (Arachis hypogea L.) as influenced by different weed control methods, Indian Journal of Plant Physiology, 20(2), 130-136. https://doi. org/10.1007/s40502-015-0151-x

Padulosi, S., Ng, N.Q. (1997). Origin, taxonomy, and morphology of Vigna unguiculata (L.)Walp. In Singh B.B.,Mohan Raj, D.R., Dashiell, K.E., Jackai, L.E.N. (eds). Advances in Cowpea Research. Co-publication Intl Inst Tropical Agric (IITA) and Japan Intl. Res.

Ranjbarfordoei, A. Samson, R. Damne, P. V. and Lemeur, R. (2000). Effects of drought stress induced by polyethylene glycol on pigment content and photosynthetic gas exchange of Pistacia khinjuk and P. mutica. Photosynthetic, 38(3), 443-447. https://doi.org/10.1023/A:1010946209484

Singh, B. B. and N'tare, (1985). Development of improved cowpea varieties in Africa. In: Singh, S.R. and Rachie, K.O. Cowpea Research, Production and Utilization. U.K.: John Wiley and Sons Chichester 105-115.

Steele, W. M. (1996). Cowpeas. In: N.W. Simmonds. Evolution of Crop Plants, London, UK: Longman. 183-185.

Terao, T., Watanabe, I., Matsunaga, R., Hakoyama, S. and Singh, B.B. (1995). Analysis of agro-physiological constraints in intercropped cowpea. Cowpea Abstracts, Second World Cowpea Research Conference, 3-7 September, Accra, Ghana.

Tutiana, K.W.O., Ibrahim, N., Cire, E.S. and Marc, N. (2006). Water condition Effects on Rhizobia competition for cowpea nodule occupancy. African Journal of Biotechnology, 5(16), 1457-1463.

Watson, D. (1952). The physiological basis of variation in yield. Advances in Agronomy, 4, 101-145. https://doi. org/10.1016/S0065-2113(08)60307-7 